\title{
Структура растительного покрова в пригородных березняках г. Красноярска
}

\section{Vegetation layer structure at Krasnoyarsk suburban birch conenoses}

\author{
Гончарова И. А. ${ }^{1,2}$, Скрипальщикова Л. Н. ${ }^{1}$ Барченков А. П. ${ }^{1}$ \\ Goncharova I. A. ${ }^{1,2}$, Skripalshikova L. N. ${ }^{1}$, Barchenkov A. P. ${ }^{1}$ \\ ${ }^{1}$ Институт леса им. В. Н. Сукачева СО РАН, г. Красноярск, Россия. \\ E-mail: iagoncharova007@mail.ru; lara_skrip_@mail.ru; alexbarchenkov@mail.ru \\ ${ }^{2}$ Красноярский краевой краеведческий музей, г. Красноярск, Россия.E-mail: iagoncharova007@mail.ru \\ ${ }^{1}$ V. N. Sukachev Institute of Forest Russian Academy of Sciences, Siberian Branch, Krasnoyarsk, Russia \\ ${ }^{2}$ Krasnoyarsk Regional Museum, Krasnoyarsk, Russia
}

Peфepam. Изучен видовой состав растительного покрова, его проективное покрытие в городских и пригородных березовых фитоценозах г. Красноярска, различных по степени антропогенного воздействия. Рассчитаны индекс Шеннона и индекс синантропизации. Определены стадии трансформации растительного покрова.

Ключевые слова. Видовой состав, индекс синантропизации, растительный покров.

Summary. The species composition of vegetation layer, its projective cover at various recreationally disturbed birch phytocenoses in Krasnoyarsk suburban zone have been studied. The Shannon index and the synanthropization index are calculated. The stages of the vegetation layer transformation are determined.

Key words. Species composition, synanthropization index, vegetation layer.

Городские и пригородные леса являются важным санитарно-гигиеническим, ветро- и почвозащитным рекреационным ресурсом. Находясь под значительным антропогенным воздействием, все ярусы фитоценоза неизбежно трансформируются. В связи с этим особо актуальной является задача изучения структуры растительного покрова как одного из наиболее уязвимых ярусов городских и пригородных лесов.

Для изучения растительного покрова в августе 2017 г. в городских и пригородных березовых фитоценозах г. Красноярска проведены геоботанические исследования по общепринятым методикам (Сукачев, Зонн, 1961). Обследованные березняки произрастают в одинаковых лесорастительных условиях с различной степенью антропогенного воздействия. Пробные площади (ПП) 1, 2, 3, 4 заложены в пригородных березняках и расположены на расстоянии 10-30 км от города в различных направлениях. ПП 5, удаленная от города на 40 км, является контролем. ПП 6, 7 расположены в черте города Красноярска. Классификация эколого-ценотических групп (ЭЦГ) видов проведена по Д. И. Назимовой и др. (2012) и Т. Н. Буториной (1963). Для сравнительной оценки флористических списков применен коэффициент Серенсена-Чекановского. Степень видового разнообразия оценена с помощью индекса Шеннона (Шмидт, 1984), степень трансформации растительного покрова - по доле участия синантропных видов в составе фитоценоза (индекс синантропизации) (Горчаковский, 1999). Названия видов даны по С. К. Черепанову (1995).

ПП 1. Березняк злаково-разнотравный. Пробная площадь расположена на надпойменной терpace p. Енисей, примыкает к автомобильной дороге. Участок подвержен сильному антропогенному влиянию (рекреация, сенокос). Установлена четвертая степень рекреационной дигрессии. Характер произрастания древостоя куртинный. Подлесок как ярус не выражен, единично отмечены Cotoneaster 
melanocarpus Fisch. ex Blytt, Rosa majalis Herrm., Spiraea chamaedryfolia L. Общее проективное покрытие растительного покрова составляет 95 \%. Доминантами и содоминантами являются Vicia unijuga А. Braun, V. amoena Fisch., Lathyrus pratensis L., Artemisia tanacetifolia L. Травяно-кустарничковый ярус разделен на 2 подъяруса: первый (высотой 70-90 см) представлен Calamagrostis epigeios (L.) Roth и $C$. arundinacea (L.) Roth, Saussurea controversa DC.; второй подъярус (высотой 30-50 см) - Artemisia incana (L.) Druce и A. tanacetifolia, Vicia unijuga. Структура фитоценоза относительно однородная, микроассоциации не выделяются. Мохово-лишайниковый ярус отсутствует.

ПП 2. Березняк разнотравно-злаковый. Пробная площадь расположена на выровненной поверхности. Нанорельеф не выражен. Участок подвержен рекреационному воздействию, развита тропиночная сеть (вторая степень рекреационной дигрессии). Подлесок (проективное покрытие 30 \%) равномерно размещен по пробной площади, разделен на 2 подъяруса. Первый подъярус представлен Cotoneaster melanocarpus, Crataegus sanguinea Pall., Malus baccata (L.) Borkh., Viburnum opulus L.; второй подъярусRosa majalis. Общее проективное покрытие растительного покрова составляет 80 \%. Степень задерненности - 50 \%. Доминируют и содоминируют Elytrigia repens (L.) Nevski, Thalictrum minus L., Vicia unijuga. Травяно-кустарничковый ярус разделен на 2 подъяруса. Первый подъярус, образованный Elytrigia repens, Thalictrum minus, Agrimonia pilosa Ledeb., достигает высоты 100 см. Второй подъярус (высотой 20-30 см) представлен Fragaria vesca L., Rubus saxatilis L., Lathyrus humilis (Ser.) Spreng. Горизонтальная структура фитоценоза не выражена. Мохово-лишайниковый покров отсутствует.

ПП 3. Березняк разнотравно-злаковый. Микрорельеф бугристо-западинный. На пробной площади отмечены следы рекреационного воздействия (третья стадия рекреационной дигрессии). Характер произрастания древостоя куртинный. Подлесок с проективным покрытием 10-20 \% размещен неравномерно (куртинами) по пробной площади, разделен на 2 подъяруса. Первый подъярус высотой 2,5-3 м имеет видовой состав: Salix caprea L., Padus avium Mill., Swida alba (L.) Opiz, Viburnum opulus. Второй подъярус высотой 0,8-1,0 м представлен одним видом: Rosa acicularis Lindl. Общее проективное покрытие травяно-кустарничкового яруса - 90 \%. Степень задерненности почвы - 70 \%. Структура фитоценоза неоднородная, выделяется 3 микроассоциации.

1. Высокотравная (доминанты: Urtica dioica L., Cannabis sativa L., Centaurea scabiosa L.) высотой $110-150$ см. Отмечена вдоль дорог и в западинах с избыточным увлажнением. Занимает 10 \% площади.

2. Разнотравная (доминанты: Geranium sylvaticum L. и G. pratense L., Phlomoides tuberosa (L.) Moench.) высотой 50-70 см. Занимает 40 \% площади.

3. Злаково-осоковая (доминанты: Elytrigia repens, Carex obtusata Lilj. и C. macroura Meinsh.) высотой 50-90 см. Занимает 50 \% площади. Мохово-лишайниковый ярус отсутствует.

ПП 4. Березняк с сосной разнотравно-осоковый. I ярус 10Б+C, II ярус 10С. Участок расположен на выровненной поверхности, примыкает к сельскохозяйственным полям, подвержен сильной рекреационной нагрузке, на пробной площади более 70 \% занимает дорожно-тропиночная сеть (четверная степень рекреационной дигрессии). Подлесок как ярус не выражен, представлен отдельными экземплярами Rosa acicularis, Padus avium, Swida alba и др. Общее проективное покрытие растительного покрова достигает $80 \%$. Степень задерненности почвы - 60 \%. В травяно-кустарничковом ярусе выделяются 2 подъяруса: первый (высота 50-70 см) состоит из Vicia unijuga, Calamagrostis arundinacea, Cimicifuga foetida L., Geranium sylvaticum; второй (высота 15-25 см) - из Lathyrus humilis, Carex macroura и др. Структура фитоценоза относительно неоднородная. Выделяется 2 микроассоциации: 1) разнотравно-злаковая. Занимает $10 \%$ пробной площади в виде узкой полосы вдоль сельскохозяйственных полей; 2) разнотравно-осоковая. Занимает 90 \% пробной площади. Мохово-лишайниковый ярус представлен в виде отдельных пятен Pleurozium schreberi (Brid.) Mitt. с проективным покрытием не более 3 \%. На пробной площади отмечены 2 клона Cypripedium calceolus L., занесенного в Красную книгу Красноярского края (Андреева, 2005).

ПП 5. Березняк с примесью сосны, разнотравно-осочковый (контроль). Участок расположен на выровненной поверхности. Подлесок редкий, яруса не образует, представлен отдельными экземплярами Rosa acicularis, Padus avium. Общее проективное покрытие растительного покрова составляет 70 $\%$. Степень задерненности почвы - 60 \%. Травяно-кустарничковый ярус дифференцирован на 2 подъ- 
яруса. Первый подъярус (высотой 70-90 см) образован Pteridium aquilinum (L.) Kuhn, Cimicifuga foetida, Vicia unijuga, Heracleum dissectum Ledeb. и др. Второй подъярус (высотой 20-30 см) представлен Carex macroura, Rubus saxatilis и др. Структура фитоценоза относительно неоднородная. Выделяются 2 микроассоциации: 1) разнотравно-орляковая. Занимает 5-10 \% площади; 2) разнотравно-осоковая. Занимает 85-90 \% площади. Мохово-лишайниковый ярус представлен в виде отдельных пятен Ptilium crista-castrensis (Hedw.) De Not. на старом валеже и Pleurozium schreberi с проективным покрытием не более 1 \%. На пробной площади отмечены несколько особей Cypripedium calceolus, занесенного в Красную книгу Красноярского края.

ПП 6. Березняк разнотравно-осочковый. Участок расположен на выровненной поверхности. Пробная площадь характеризуется второй степенью рекреационной дигрессии. Подлесок размещен неравномерно по пробной площади (куртинами), проективное покрытие $30 \%$, разделен на 2 подъяруca. В видовом составе первого яруса присутствуют Salix caprea, Malus baccata, Padus avium и др.; второго яруса - Rosa majalis. Степень общего проективного покрытия 70 \%, степень задерненности почвы 40 \%. Доминантом травяно-кустарничкового яруса является Carex macroura. Травяно-кустарничковый ярус дифференцирован на 2 подъяруса. Первый подъярус (высотой 70-100 см) представлен Crepis sibirica L., Aconitum barbatum Pers., Centaurea scabiosa и др., второй подъярус (высотой 15-20 см) Carex macroura, Rubus saxatilis, Vicia unijuga и др. Структура фитоценоза относительно неоднородная. Выделяется 2 микроассоциации: 1) осоковая (образована Carex macroura). Занимает 70 \% площади; 2) разнотравная (образована Vicia unijuga, Agrimonia pilosa, Maianthemum bifolium (L.) F.W. Schmidt и др.). Занимает 30 \% площади. Мохово-лишайниковый ярус слабо выражен, представлен в виде отдельных дерновин Pleurozium schreberi и Plagiomnium ellipticum (Brid.) T. J. Kop.

ПП 7. Березняк разнотравный. Участок расположен на склоновой поверхности крутизной $1-2^{0}$ С3 экспозиции, примыкает к автомагистрали, отмечена третья степень рекреационной нагрузки. Подлесок выражен как ярус, имеет проективное покрытие $15 \%$, разделен на 2 подъяруса. Первый подъярус (высота 1,5-2,0 м) образован Padus avium, Malus baccata, Salix caprea; второй подъярус (высота 50-100 см) - Spiraea media Schmidt, Rosa majalis. Общее проективное покрытие составляет 90 \%. Степень задерненности почвы - 20 \%. Доминантами и содоминантами травяно-кустарничкового яруса являются Agrimonia pilosa, Polygonatum odoratum (Mill.) Druce, Cimicifuga foetida и др. Вертикальная и горизонтальная структура фитоценоза однородна. Мохово-лишайниковый покров не выражен.

Индекс видового разнообразия (индекс Шеннона) варьирует в пределах 2,33-3,53 (табл. 1). Наибольшим видовым разнообразием характеризуется ПП 7 (индекс Шеннона составляет 3,53 ), наименьшим - ПП $6(2,33)$.

Таблица 1

Индекс видового разнообразия и индекс синантропизации в березовых ценозах

\begin{tabular}{|l|c|c|c|c|c|c|c|}
\hline Пробные площади & ПП 1 & ПП 2 & ПП 3 & ПП 4 & ПП 5 & ПП 6 & ПП 7 \\
\hline Индекс Шеннона & 2,93 & 2,96 & 3,36 & 2,60 & 2,55 & 2,33 & 3,53 \\
\hline $\begin{array}{l}\text { Индекс } \\
\text { синантропизации }\end{array}$ & 11,9 & 16,7 & 32,7 & 6,9 & 0 & 16,0 & 9,3 \\
\hline
\end{tabular}

В изучаемых березовых ценозах было отмечено 12 видов кустарников, 113 видов травяно-кустарничкового яруса и 3 вида мхов. Значение коэффициента сходства Серенсена-Чекановского между флористическими списками на пробных площадях варьирует от 0,34 до 0,63 (табл. 2). Пробная площадь 2 , подверженная и техногенным, и сильным рекреационным нагрузкам, имеет наименьший коэффициент сходства $\mathrm{K}_{\mathrm{sc}}$ с остальными пробными площадями.

Анализ видового состава исследуемых ценозов показал, что основную массу видов, произрастающих на всех пробных площадях, составляют растения, относящиеся к светлохвойной лесной поясно-зональной группе (38,7-58,9\%). Синантропные виды вносят значительный вклад $(6,9-32,7$ \%) в растительный покров всех пробных площадей, кроме ПП 5 (контроль), где индекс синантропизации равен 0 (табл. 1). Согласно шкале антропогенной трансформации растительных сообществ (Прокопьев, Ры- 
бина, 2010), пробные площади 4, 7 находятся на начальной фазе, пробные площади 1, 2, 6 - на заключительной фазе стадии слабой трансформации. Тогда как пробная площадь 3 проходит заключительную фазу стадии умеренной трансформации.

Таблица 2

Коэффициент сходства видового состава на пробных площадях в березовых фитоценозах

\begin{tabular}{|c|c|c|c|c|c|c|}
\hline $\begin{array}{c}\text { Пробные } \\
\text { Площади }\end{array}$ & ПП 2 & ПП 3 & ПП 4 & ПП 5 & ПП 6 & ПП 7 \\
\hline ПП 1 & 0,59 & 0,38 & 0,51 & 0,43 & 0,34 & 0,52 \\
\hline ПП 2 & & 0,47 & 0,62 & 0,45 & 0,43 & 0,55 \\
\hline ПП 3 & & & 0,43 & 0,34 & 0,4 & 0,42 \\
\hline ПП 4 & & & 0,53 & 0,45 & 0,63 \\
\hline ПП 5 & & & & & 0,38 & 0,52 \\
\hline ПП 6 & & & & & 0,44 \\
\hline
\end{tabular}

Благодарности. Работа выполнена при финансовой поддержке договора НИР № 29.03.04/2019 «Изучение устойчивости антропогенно нарушенных лесных экосистем в зонах длительного воздействия техногенных факторов».

\section{ЛИТЕРАТУРА}

Aндреева E. Б. Венерин башмачок обыкновенный — Cypripedium calceolus L. // Красная книга Красноярского края: Растения и грибы. - Красноярск: Поликом, 2005. - С. 129.

Буторина Т. Н. Эколого-ценотический анализ кустарничково-травяного яруса лесных ассоциаций // Типы лесов Сибири. - М.: Изд-во Академии наук СССР, 1963. - С. 31-52.

Горчаковский П. Л. Антропогенная трансформация и восстановление продуктивности луговых фитоценозов. - Екатеринбург: Изд-во «Екатеринбург», 1999. - 156 с.

Красная книга Красноярского края. Растения и грибы. - Красноярск: Поликом, 2005. - 368 с.

Назимова Д. И, Дробушевская О. В., Данилина Д. М., Коновалова М. Е., Кофман Г. Б., Бугаева К. С. Биоразнообразие и динамика низкогорных лесов Саян: региональный и локальный уровни // Разнообразие и динамика лесных экосистем России. - М.: Тов-во научных изданий КМК, 2012. - Кн. 1. - С. 131-173.

Прокопьев Е. П., Рыбина T. А. Опыт мониторинга синантропизации и антропогенной трансформации растительного покрова особо охраняемых природных территорий г. Томска // Вестник Томского гос. ун-та. Биология, 2010. - № 3 (11). - C. 109-118.

Сукачев В. Н., Зонн С. В. Методические указания к изучению типов леса. - М.: Из-во АН СССР, 1961. - 144 с.

Черепанов $\boldsymbol{C} . \boldsymbol{K}$. Сосудистые растения России и сопредельных государств. - С.-Пб.: Мир и семья, 1995. $990 \mathrm{c}$.

Шмидт В. М. Математические методы в ботанике. - Л.: Изд-во Ленингр. ун-та, 1984. - 288 с. 